\title{
Aspecte istorico-liturgice, pastorale și muzicale privitoare la Slujba înmormântării mirenilor
}

Abstract: Historical, liturgical, pastoral and musical aspects regarding the Office for the burial of a layman. Similarly to the Holy Sacraments, the funeral service used to be celebrated within the Eucharist, as witnessed by ancient testimonies. The current service is the result of the merging of elements proper to the Constantinopolitan Studite tradition and the monastic Sabaite practice. Gradually, the structure of the Matins incorporated elements of the studite hymnography (Antiphons and Hymns) and elements of the sabaite hymnography (the Kanon), so that between the $10^{\text {th }}-12^{\text {th }}$ centuries, the funeral office gained an unique form. Prayers and hymnography (such as Kanons) were added according to the different types of the dead: laymen, infants, celebrants, monks and bishops. During the time of St. Symeon of Thessalonika, the funeral service for laymen was structured close the the rite known today. Full of theological meaning, the funeral rite emanates both a catechetical and educative character, as well as a pastoral one, focusing on the importance of living an earthly life which is guided by the evangelical spirit, as a preparation for the Great Passing towards the highest step of eternal holiness and communion with the Holy Trinity. One feature of this office is that it is sung. The purpose is to offer hope, spiritual strength and comfort to the sorrowful. Therefore, some of the most famous Romanian precentors and church music professors have

* Preot, Lect. univ. la Facultatea de Teologie Ortodoxă „Justinian Patriarhul”, Universitatea din București, România.

** Pe această cale, adresez mulțumiri Domnului drd. Mihail Qaramah pentru unele sugestii făcute și pentru furnizarea câtorva materiale în vederea redactării finale a acestui studiu. 
composed the music for the funeral office of a layman, in order to enrich this liturgical order and to support the missionary work of our Church among its spiritual sons. In the context of the pandemic, addressing the theme of funeral is indisputable, because it can help us rediscover the real meaning of life, which unfortunately, many have left behind.

Keywords: burial rite, Euchologion, hymnography, prayers, funeral chant, Byzantine liturgical tradition, church music.

\section{Aspecte preliminare}

În perspectiva unui demers științific, nu se poate vorbi despre ritualul liturgic ortodox al înmormântării fără a lua în considerare fazele evolutive ale acestei slujbe deosebit de bogate în semnificații teologice, simbolico-liturgice și pastorale. Precizăm faptul că în tradiția ortodoxă, Slujba înmormântării ${ }^{1}$, asemenea celorlalte rânduieli litugice ale corpusului ecleziastic, este produsul evoluției și fuziunii unor rânduieli tipiconale, imnografice și evhologice proprii diferitelor comunități creștine aflate în întreg Răsăritul Ortodox². Dumnezeiasca Liturghie a

${ }^{1}$ În Molitfelnicele vechi românești, pentru slujba înmormântării întâlnim termenul de Pogribanie, preluat din limba slavonă. În cărțile de cântări bisericești întâlnim expresiile: Prohod sau Epitaf (grec) pentru Slujba Înmormântării Domnului nostru Iisus Hristos, cf. MACARIE IEROMONAHUl, Prohodul Domnului, Buzău, Tipografia Episcopiei Buzăului, 1836 şi Anton PANN, Epitaful sau Slujba Înmormântării Domnului și Mîntuitorului nostru Isus Hristos, București, Tipografia de Muzică Bisericească, 1846 și 1853. Această rânduială ce are loc în Sfânta și Marea Sâmbătă mai poartă denumirea de Laudele îngropării Domnului. În popor întâlnim deseori expresia prohodire, când vine vorba despre Slujba înmormântării celor adormiți..

2 Cercetările întreprinse pe tărâmul vieții liturgice au dat la iveală faptul că slujbele Bisericii Ortodoxe sunt produsul sintezei dintre Tipicul asmatic constantinopolitan și cel monastic ierusalimitean. Marea Biserică a Constantinopolului a elaborat rânduielile liturgice solemne, specifice ritului ecleziastic. Aici se regăsește și Rânduiala Slujbei Cântate (Akolouthia Asmatike) a Marii Biserici. Centrului monastic al Sf. Sava i-a revenit meritul de a oferi întregii Biserici Ortodoxe producțiile imnografice de tropare, condace, canoane și stihiri altoite pe rânduielile tipiconale ale Marii Biserici. Despre chestiunea marii sinteze tipiconale, a se vedea Robert TAFT, Ritul bizantin -scurtă istorie-, trad. Dumitru Vanca și Alin Meheș, Alba Iulia, Edit. Reîntregirea, 2008. 
reprezentat dintru început, și reprezintă și astăzi, coloana vertebrală a întregii vieți liturgice ortodoxe. Atât Sfintele Taine, cât și celelalte rânduieli bisericești s-au aflat timp de secole într-o legătură organică cu Sfânta Liturghie, de care s-au desprins în timp, ajungându-se la separaţia din zilele noastre, fapt pricinuit de diverși factori ecleziastici și sociali. Bunăoară, nu trebuie să ne mire faptul că astăzi mulți dintre credincioşii noștri au pierdut înțelesul profund al cultului litugic și că doar o reconsiderare a centralității Sfintei Liturghii în viața noastră poate constitui cheia înțelegerii profunde și nealterate a spiritualităţii liturgice ortodoxe. Slujba înmormântării mirenilor, la care ne vom referi în cele ce urmează, a fost alcătuită pe structura Utreniei. Denumirea de Panihidă, ne duce cu gândul la perioada primelor secole creștine, în care privegherea se săvârșea în timpul nopții. De fapt, chiar termenul panihidă înseamnă priveghere sau cântare de toată noaptea, care culmina cu Rânduiala Sfintei Liturghii, așa cum se întâmplă şi acum în mănăstiri. Așadar, înmormântarea unuia dintre creștini nu era un act liturgic privat, ci se desfășura în mijlocul comunității euharistice, adică în cadrul Sfintei Liturghii ${ }^{3}$. Dincolo de toate aceste aspecte referitoare la etapele formării Rânduielii înmormântării, care sunt extrem de necesare îndeosebi pentru cercetarea teologico-liturgică, trebuie subliniat că această slujbă, prin textele ei evhologice și imnografice, constituie un memorial teologic care reflectă pe de o parte, istoria creării și căderii omului, iar pe de altă parte, restaurarea lui în Iisus Hristos și adevărul despre viața veacului ce va să fie. Din acestă perspectivă, frumusețea Rânduielii înmormântării și profunzimea imnelor sale, ne descoperă grija Bisericii pentru cei adormiți, ca

${ }^{3}$ Legătura Slujbei înmormântării cu Sfânta Liturghie poate fi observată și în tradiția liturgică a Bisericii Romano-Catolice, prin prezența în Requiem (Parastas) a unor secvențe consacrate Missei, precum: Kyrie, Offertorium, Sanctus, Agnus Dei și Communio. Începând din secolul al XV-lea, o seamă de compozitori au alcătuit astfel de lucrări vocal-simfonice denumite la început „Missa pro defunctis” sau Recviem (Missa Recviem). Compozitorul Adrian Pop face un sinoptic comparativ între Recviemul catolic și Parastasul ortodox, în lucrarea: Recviemul românesc, Cluj-Napoca, Edit. Media Musica, 2004, pp. 31-37. 
fii ai ei, în momentul trecerii către stadiul cel mai înalt al vieții lor spirituale, dar și grija, mângâierea și încurajarea pe care le arată celor rămași în viață, ca un remediu în purtarea crucii personale și în vindecarea suferinței provocate de pierderea celor dragi. Mai mult decât atât, reține atenția caracterul catehetic-educativ al acestei rânduieli care, în acelaşi timp, constituie și o invitaţie la reflecție și la adâncirea sensurilor profunde ale vieții.

\section{Câteva mărturii patristice cu privire la Rânduiala înmormântării}

În primele patru secole nu avem mărturii detaliate cu privire la rânduiala de înmormântare. De regulă, cimitirele erau situate în afara orașelor ${ }^{4}$. Cunoaștem, din mărturiile unor istorici și ale unor Sfinți Părinți, că trupurile celor adormiți erau însoțite către cimitire de către creștini cu psalmi și cu imne, purtând lumini în mâini. Astfel, Sfântul Ioan Gură de Aur ne vorbește despre cinstea pe care i-au arătat-o creștinii din Antiohia Sfântului Sfințit Mucenic Vavila, cu prilejul strămutării moaștelor Sfântului de la Dafne în Antiohia, în vremea împăratului Iulian Apostatul (361-363) $)^{5}$. O altă mărturie importantă este cea referitoare la ritualul de înmormântare al împăratului Constantin cel Mare. Eusebiu de Cezareea relatează momentul acesta memorabil astfel:

${ }^{4}$ În ceea ce îi privește pe creștini, mormintele acestora aveau inscripționate pe ele simboluri creștine. Cei care merg în pelerinaj la Catacombele de la Roma pot observa această practică din perioada Creștinismului primar. În aceste catacombe, săpate în tuf, erau înmormântați și cetățeni de religie păgână, iar pe mormintele lor pot fi observate anumite simboluri zoomorfe, ornamente florale sau alte simboluri religioase specifice.

5 Părintele antiohian afirmă: ,Că atunci când mucenicul se întorcea din Dafne, tot orașul ni s-a revărsat pe uliță; goale de bărbați erau piețele, goale de femei erau casele, pustii de fecioare erau iatacurile. Astfel, oamenii din oraș, de toate vârstele, și bărbați, și femei, au ieșit în grabă ca pentru a primi pe un tată pe care nu 1-au văzut de multă vreme și care se întorcea dintr- o călătorie îndepărtată...”, în: „Cuvânt de laudă la Sfântul Sfințit Mucenic Vavila” (SF. IOAN GURĂ DE Aur, Predici la sărbători împărătești și cuvântări de laudă la sfinți, trad. Dumitru Fecioru, București, Edit. Institutului Biblic și de Misiune al Bisericii Ortodoxe Române, 2002, p. 298). 
„Ajungând la Biserica Apostolilor Mântuitorului, aceștia [ostaşii; n.n.] au depus sarcofagul, îngăduind noului împărat, Constanțiu, să-și cinstească părintele atât prin prezența sa cât și printr-a tuturor celor de față, și să plinească tot ce-i cerea lui solemnitatea clipei. Mai apoi el s-a retras (de o parte), și unităţile de soldați i-au urmat exemplul. În mijloc au păşit slujitorii lui Dumnezeu, puhoiul curioșilor și mulțimea credincioșilor, toată; iar aceia au săvârșit dumnezeiasca slujbă a înmormântării, înălțând cuvenitele rugăciuni. Culcat în înaltul acelei platforme, fericitul Constantin primea dovada măreției sale: nemaistăpânindu-și lacrimile, mulțimea nenumărată a poporului își unea glasul cu preoții lui Dumnezeu, strigându-i Acestuia cu glas de jale rugile lor spre (mântuirea) sufletului împăratului, şi astfel îndeplinind fierbintea dorință a acelui om atât de plăcut lui Dumnezeu"•.

Despre momentul mutării la cele veșnice a Sfântului Vasile cel Mare, Arhiepiscopul Cezareei Capadociei, Sfântul Grigorie Teologul relatează următoarele:

„...Vasile, rostind cuvintele: În mâinile Tale depun sufletul $m e u$, şi-a dat sufletul în mâinile îngerilor, care aveau să-l conducă (spre cer), dar aceasta după ce mai întâi a dat celor prezenți învăţături asupra credinței și prin sfaturile lui i-a determinat să devină mai buni. Apoi s-a văzut un lucru mai mare decât toate cele ce s-au văzut vreodată. Acest bărbat sfânt a fost purtat pe brațele sfinților. Care mai de care se silea să pună mâna sau măcar să atingă, unul poala veșmântului, altul umbra, altul năsălia pe care era purtat sfântul, căci ce putea fi mai sfânt și mai curat decât trupul lui? Alții se îmbulzeau să se apropie măcar de cei ce-1 purtau, alții ca măcar să-1 privească, în credința că şi aceasta le poate fi de folos. Se umpluseră piețele, porticele, etajul al doilea și al treilea, de cei ce-l petreceau,

${ }^{6}$ Eusebiu de CezareeA, Viața lui Constantin cel Mare. Scrieri partea a doua, introd. Emilian Popescu, trad. Radu Alexandrescu, în col. „Părinți și Scriitori Bisericești”, 14, București, Edit. Institutului Biblic şi de Misiune al Bisericii Ortodoxe Române1991, p. 187. 
unii mergând înainte, alții în urmă sau alături de el, înghesuiți unii în alții. Erau multe zeci de mii, de toate neamurile, de toată vârsta, unii chiar necunoscuți. Cântările de psalmi erau înăbușite de plânsete, iar tăria de suflet a tuturor era biruită de durere... $\mathrm{Cu}$ greu trupul a fost smuls din îmbulzeală, care aproape strivise pe cei ce-l duceau, și astfel a fost redat mormântului părinților săi..."”.

De asemenea, Sfântul Grigorie de Nyssa ne relatează că la moartea surorii sale, Macrina, s-au cântat psalmi și imne ${ }^{8}$, iar Sfântul Grigorie Teologul ne oferă aceleași informații cu privire la înmormântarea fratelui său, Chesarie ${ }^{9}$. Toate aceste mărturii nu ne vorbesc însă despre o rânduială liturgică de înmormântare, ci doar despre atmosfera de rugăciune instituită cu prilejul trecerii în veșnici a acestor mari personalităţi ale lumii creștine.

\section{Elemente din Rânduiala înmormântării aflate în cele mai vechi documente bisericești}

\subsection{Constituțiile Apostolice}

Această colecție de prevederi bisericești, datată în preajma anului 380, din Antiohia, constituie unul dintre cele mai vechi şi însemnate documente creștine în care se face o descriere detaliată a rânduielilor liturgice bisericești din secolul al IV-lea. În cap. $\mathrm{XXX}^{10}$

${ }^{7}$ Sf. Grigorie Teologul, Panegiric (Cuvânt de laudă) la Sfântul Vasile cel Mare, trad. Nicolae Donos, București, Edit. Institutului Biblic și de Misiune Ortodoxă, 2009, pp. 158-159. Panegiricul a fost publicat recent în volumul cu text bilingv, în limbile greacă veche și română, intitulat: SF. GRIGORIE TeOlogul, Opere VI, Cuvinte Encomiastice, introd. și trad. Adrian Tănăsescu, Cristina Rogobete și Cornel Coman, București, Editura Gândul Aprins, 2020, pp. 519 -521.

8 SF. GRIGORIE DE NySSA, Viața Macrinei, PG XLVI, 992-993, apud Ene BRANIȘTE, Liturgica Specială pentru institutele teologice, București, Edit. Institutului Biblic și de Misiune al Bisericii Ortodoxe Române, 1980, p. 489.

9 Sf. Grigorie Teologul, Cuvântarea a VII-a, PG XXXV, 755, apud E. BRANișTE, op. cit., p. 489.

${ }^{10}$ Capitolul la care ne referim se intitulează: „Că obiceiul iudeilor și păgânilor de a respecta curățirile naturale și a se scârbi de rămăşițele celor morți e străin creștinilor, care trebuie chiar să se ducă în cimitirele sfinților și să cânte psalmi 
al cărții a VI-a, intitulată, Despre schisme și erezii, ne sunt înfățişate prescripții referitoare la cinstea ce trebuie acordată celor adormiți. Contrar obiceiurilor iudaice și păgâne, potrivit cărora cel care se atinge de trupul celui mort este întinat, aici se recomandă adunările în cimitire și comemorarea celor adormiți, îndeosebi prin săvârșirea în biserici şi cimitire a Sfintei Liturghii. Acest text vechi ne arată tocmai legătura strânsă dintre ritualul înmormântării şi săvârşirea Dumnezeieștii Euharistii. În cartea a VIII-a a Constituțiilor Apostolice, în capitolul XLI, ne este descris momentul de pomenire a celor adormiți în dreapta credință, în cadrul Sfintei Liturghii. După cererea specială a diaconului ${ }^{11}$ urma rugăciunea de iertare pe care o spunea episcopul ${ }^{12}$, iar apoi, o

pentru cei adormiți în credință”. Creștinii sunt îndemnaţi să cinstească pe martiri, pe sfinți și pe cei din veac adormiți, astfel: „Nu păziți cu scrupulozitate cele cu privire la cele legiuite și naturale, socotind că vă întinați prin ele, şi nu căutați îndepărtări iudaice, băi continue sau curățiri nici la atingerea unui mort (Nm 19, 11-18). Ci adunați-vă fără nici un scrupul în cimitire, făcând citirea cărților sfinte şi cântând psalmi pentru martirii adormiţi și pentru toţi sfinții cei din veac, precum și pentru frații voștri adormiți în Domnul; aduceți în bisericile voastre și în cimitire drept Euharistie primită închipuirea (antitypon) Trupului împărătesc al lui Hristos, iar la ieșirea celor adormiți însoțiți-i cântând psalmi, dacă sunt credincioși în Domnul (... ) De aceea și voi, episcopii și ceilalți, atingându-vă fără vreun scrupul de cei adormiți, nu socotiți că vă întinați, nici nu vă scârbiți de rămășițele lor, evitând astfel de scrupule, fiindcă sunt neghiobii. Și împodobiți-vă cu sfințenie și cumințenie, ca să vă faceți părtaşi ai nemuririi şi Împărăției lui Dumnezeu și să primiţi făgăduința lui Dumnezeu, odihnindu-vă în chip veșnic prin Iisus Hristos Mântuitorul”, cf. diacon Ioan I. ICĂ jr, Canonul Ortodoxiei, vol. I: Canonul Apostolic al primelor secole, Sibiu, Edit. Deisis/Stavropoleos, 2008, pp. 710 -711.

11 Textul cererii: „Să ne rugăm și pentru frații noștri adormiți în Hristos; să ne rugăm pentru adormirea cutăruia sau cutăruia $(N)$, ca primind sufletul său Dumnezeul Cel Iubitor de oameni să-i treacă cu vederea orice păcat cu voie și fără voie, și fiindu-i milostiv și binevoitor să-1 rânduiască în locul binecinstitorilor care sunt în sânurile lui Avraam $(L c .16,22)$, Isaac și Iacov împreună cu toți cei care din veac I-au bineplăcut $(F c .5,24)$ și au făcut voia Lui, de unde a fugit orice durere, întristare și suspinare (Is. 35, 10). Să ne sculăm. Pe noi înșine și unii pe alții să ne dăm veșnicului Dumnezeu prin Cuvântul dintru început”, cf. I. I. ICĂ jr, op. cit., p. 765.

12 Textul rugăciunii: „Cel ce prin fire ești fără de moarte și fără de sfârșit, de Care s-a făcut tot ce-i nemuritor și muritor, Cel ce pe vietatea cuvântăroare, 
rugăciune a plecării capetelor, de mulțumire, pe care o rostea tot episcopul. Tot aici, în cap. XLII, sunt prezentate zilele de pomenire a celor adormiți: la 3, 9, 30 de zile și la un $a^{13}$.

\subsection{Evhologhionul lui Serapion de Thmuis}

Această colecție de rugăciuni a episcopului egiptean Serapion de Thmuis datează din aceeași perioadă a secolului al IV-lea. Episcopul Serapion a trecut la cele veșnice în anul $362^{14}$. În cadrul acestei colecții apare și o rugăciune pentru cel ce a murit și e purtat afară. După conținutul ei, în mod prezumtiv, putem considera că a stat la baza alcătuirii rugăciunilor a V -a și a VI-a de la „Vecernia plecării genunchilor” ce se săvârșește în Lunea Rusaliilor, deoarece un fragment al acesteia se regăsește în conținutul acelor rugăciuni ${ }^{15}$.

omul, cetățean al lumii, 1-ai făcut muritor și i-ai făgăduit înviere, cel ce pe Enoh și pe Ilie nu i-ai lăsat să facă experiența morții; Dumnezeul lui Avraam, Dumnezeul lui Isaac și Dumnezeul lui Iacov, nu ești Dumnezeul morții, ci al viilor (Mt. 22, 33), pentru că sufletele tuturor sunt vii la Tine (Lc. 20, 38), duhurile drepților sunt în mâna Ta și de ele nu se vor atinge chinuri $($ Sol. 3,1$)$ căci toți cei sfințiți sunt în mâinile Tale (Dt. 33, 5). Însuți și acum privește peste robul Tău acesta, pe care 1-ai ales și 1-ai luat la Tine spre o altă soartă și-i iartă orice a păcătuit cu voie sau fără voie, trimite-i în jur îngeri binevoitori, și-1 rânduiește în sânul patriarhilor, profeților și apostolilor și ale tuturor celor ce au bineplăcut Ție în veac, unde nu este întristare, durere și suspin (Is. 35, 10), în locul dreptcredincioșilor și în pământul celor drepți și al celor ce văd slava Hristosului Tău (In.17, 24). Prin Care fie Ție slavă, cinste și venerare, mulțumire și închinare în Sfântul Duh în veci. Amin., cf. I. I. ICĂ jr, op. cit., pp. 765-766.

${ }^{13}$ I. I. ICĂ jr, op. cit., op. cit, p. 766. În legătură cu grija creștinilor și a Bisericii față de cei săraci pe care nu are cine să-i înmormânteze sau să-i pomenească, găsim o prescripție în: Testamentul Domnului prin Clement Romanul (Testamentum Domini), în Cartea a II-a, cap. XXIII, cf. I. I. ICĂ jr, op. cit., p. 832.

${ }^{14}$ Cf. I. I. ICĂ jr, op. cit., p. 865.

15 Redăm aici textul rugăciunii: „Dumnezeule, Care ai puterea asupra vieții și a morții, Dumnezeule Care omori și faci viu, Care ai coborât la porțile iadului și Te-ai ridicat de acolo, Care zidești duhul omului în el și iei sufletele sfinților și le dai odihnă, Care schimbi, prefaci și preschimbi făpturile tale aşa cum e drept şi potrivit, Cel ce singur ești nestricăcios, neschimbat și veșnic, Ție ne rugăm pentru adormirea și odihna robului Tău acesta $(N)$; odihnește sufletul lui în loc de vredeață, în cămări de odihnă împreună cu 
3.3. Ierarhia cerească și Ierarhia bisericească a lui Dionisie Pseudo-Areopagitul

În partea a doua a cărții intitulate Ierarhia bisericească, autorul face o descriere a ritualului înmormântării unui cleric, astfel:

\begin{abstract}
„Adunând dumnezeiescul ierarh corul preoțesc, dacă cel mort a făcut parte din rânduiala sacerdotală, și așezându-1 pe cel adormit în fața dumnezeiescului altar, începe el rugăciunea și mulțumirea cea către Dumnezeu. Iar dacă cel adormit era din rândul monahilor celor fără păcat sau al sfintei comunități, atunci îl aşază pe el lângă cinstitul presviteriu, înaintea intrării preoților. În urmă, ierarhul termină rugăciunea de mulțumire către Dumnezeu; diaconii citesc pe rând făgăduințele cele nemincinoase cuprinse în dumnezeieștile Scripturi despre sfânta noastră înviere, și cu evlavie cântă cântările psalmistice, care au același cuprins și înțeles. După acestea primul dintre diaconi sloboade pe catehumeni; pomenește pe sfinții ce au adormit înainte; învrednicește și pe cel adormit acum de aceeași pomenire și îndeamnă pe toți să se roage pentru sfârșitul său cel fericit în Hristos. În cele din urmă divinul ierarh, păşind spre mort, face o rugăciune prea sfântă pentru dânsul și, după rugăciune, ierarhul însuși sărută pe cel adormit, iar după el toți cei de față. După ce au sărutat cu toții, ierarhul toarnă untdelemn peste cel adormit, așază trupul într-un loc de cinste, împreună cu celelalte trupuri sfinte din același ordin" ${ }^{\prime \prime}$.
\end{abstract}

Avraam, Isaac și Iacov și cu toți sfinții Tăi; iar trupul acesta învie-1 în ziua în care ai rânduit-o potrivit făgăduințelor. Tale nemincinoase, ca să-i dai lui și moștenirile cele după vrednicia lui în sfintele Tale pășuni, neaducându-Ți aminte de greșelile lui, iar ieșirea lui fă-o să fie cu pace și binecuvântată; tămăduiește cu duh de mângâiere întristările celor care-1 conduc acum (pe ultimul drum) și nouă tuturor ne dă un sfârşit bun, prin Unul-Născut al Tău Iisus Hristos. Că Tie se cuvine slava și puterea în toți vecii vecilor. Amin". Cf. I. I. ICĂ jr, op. cit., pp. 866-867.

16 Pseudo-Dionise Areopagitul, Ierarhia cerească, Ierarhia pământească, trad. Cicerone Iordăchescu, Chișinău, Tipografia Eparhială „Cartea Românească”, 1932, pp. 141-142. Se observă din textul citat, faptul că diaconii îi concediau pe catehumeni din sinaxa liturgică, lucru care ar lăsa să 
Totodată, autorul cărții pomenește de rugăciunea pe care o rostește episcopul pentru cel adormit înainte de sărutarea sfântă, prin care îl roagă pe Dumnezeu să-1 ierte pentru cele săvârșite în viață din pricina slăbiciunilor omenești și să-1 învrednicească de lumină și în țara celor vii, în sânurile lui Avraam, Isaac și Iacov, în locul unde nu este durere, nici întristare, nici suspin ${ }^{17}$. Această relatare din secolele V-VI este deosebit de importantă pentru cunoașterea evoluției rânduielii înmormântării, deoarece ne prezintă forma embrionară a acestei slujbe, care se săvârșea în cadrul Sfintei și Dumnezeieștii Liturghii.

se înțeleagă că rânduiala aceasta de înmormântare ar fi fost integrată în Slujba Sfintei Liturghii. Liturgistul N. Miloșevici consideră că descrierea lui Dionisie ar face aluzie la o rânduială de îngropare care avea loc distinct de Slujba Sfintei Liturghii. Invocarea sa privitoare la canonul 41 al Sinodului local de la Cartagina, potrivit căruia Sfintele altarului pot fi săvârșite doar de către cei care au ajunat, iar de se va întâmpla ca cineva să se săvârșească din viață spre seară, să se facă numai rugăciuni pentru el, dacă slujitorii au prânzit, nu pare destul de convingătoare, ci poate fi considerată doar o ipoteză (Nenad S. MiLoșEVICI, Dumnezeiasca Liturghie - centru cultului în Ortodoxie. Legătura indisolubilă a sfintelor Taine cu dumnezeiasca Euharistie, trad. Ioan Ică sr., Sibiu, Deisis, 2012, pp. 212-213. În sprijinul afirmației legăturii Rânduielii înmormântării cu Sfânta Liturghie stă și mărturia Fer. Augustin, care relatează faptul că în timp ce mama sa nu era încă înmormântată, se aducea jertfa mântuirii noastre (Sfânta Euharistie), pentru pomenirea ei: „Când, apoi, trupul a fost ridicat, ne-am dus și ne-am întors fără nico lacrimă. Căci eu nu am plâns, nici în timpul acelor rugăciuni, pe care le-am rostit Ție, când se aducea pentru ea jerfta răscumpărării noastre, în timp ce trupul neînsuflețit era depus lângă mormânt, mai înainte de a fi depus, așa cum este obiceiul să se facă acolo..." [FER. Augustin, Confessiones (Mărturisiri), trad. Docent Nicolae Barbu, introd. Ioan Rămureanu, București, Edit. Institutului Biblic și de Misiune al Bisericii Ortodoxe Române, 1994, p. 274]. Pomenirea celor adormiți era o practică și o datorie de suflet firească, așa cum este şi astăzi. În acelaşi capitol, în cuvintele testament adresate fiilor săi, Monica le cere un singur lucru, să o pomenească la Sfânta Liturghie: „Îngropați acest trup oriunde, să nu vă tulbure nicio grijă de el, un singur lucru vă rog, anume, la altarul Domnului să vă amintiți de mine, oriunde veți fi”" (Ibidem, p. 272). Așadar, rugăciunile de pomenire a celor adormiți la Sfânta Liturghie au fost dintru început o lucrare a întregii Biserici Creștine.

17 Ibidem, p. 144. 
3.4. Codicele Barberini Gr. $336^{18}$

Acest Evhologhiu-manuscris, asemenea celorlalte documente prezentate mai sus, nu conține o rânduială ( $\dot{\alpha} \kappa o \lambda o v \theta i ́ \alpha)$ de înmormântare, ci numai șapte rugăciuni, după cum urmează: 1 . „Rugăciune pentru cel ce s-a săvârșit” (Dumnezeul duhurilor și a tot trupul... $)^{19}$; 2. „Rugăciune de mângâiere a celor întristați de pierderea celui adormit, pe care o rostește preotul" (Doamne, Doamne, Cel ce ești mângâierea celor necăjiți...); 3. „Altă rugăciune pentru cel ce s-a săvârșit”" (Dumnezeul nostru, Dumnezeul mântuirii... $)^{20}$; 4. „Altă rugăciune pentru cel ce s-a săvârșit” (Dumnezeule Cel bun și iubitor de oameni...); 5. „Altă rugăciune de îngropare universală" (Stăpâne, Dumnezeul

${ }^{18}$ Codex Barberini graecus 336 este cel mai vechi manuscris liturgic grec păstrat până azi. Datează de la sfârşitul secolului al VIII-lea și este copiat pe pergament în uncială biblică greacă târzie, de tip occidental, undeva în sudul Italiei, înainte de anul 800. În sec. al XIV-lea, manuscrisul se afla în posesia unui bibliofil din Florența, pe nume Niccolo Niccoli, de la care a trecut prin testament, în anul 1441, în biblioteca mănăstirii dominicane San Marco. De aici, mai tâziu a intrat în biblioteca Barberini din Roma, iar în anul 1902, fiind achiziționat de papa Leon XIII, a intrat în fondurile Bibliotecii Apostolice Vaticane. Editat parțial de Jacques Goar, în anul 1647, în faimosul său Euchologhion, în sec. XX, codicele a făcut obiectul mai multor intenții de editare. Acest lucru s-a materializat în anul 1996, când doi tineri cercetători, discipoli ai profesorului liturgist Miguel Arranz din Roma, Stefano Parenti și Elena Velkovska 1-au publicat sub titlul: L'Eucologio Barberini gr. 336, col. „Bibliotheca Ephemerides Liturgicae Subsidia”, 80, Roma, Edizioni Liturgiche, 1996, cf. I. I. ICĂ jr, op. cit., p. 281.

${ }^{19}$ Dintre cele șapte rugăciuni pentru cei adormiți, existente în acest codex, această primă rugăciune a intrat în rânduiala de înmormântare, ca rugăciune de dezlegare și de ieratare. În rânduielile noastre actuale, aceasta se rostește și la priveghi, când se citesc stâlpii evangheliilor, în ziua înmormântării unui adormit, la parastase, precum și la Rânduiala Panaghiei și la Litia mică. După conțiuntul ideilor, această frumoasă rugăciune își are obârşia în textele euhologice mai vechi, consemnate în documentele patristice prezentate anterior. Vom vedea că ultimele două rugăciuni de iertare mai lungi din rânduiala înmormântării actuale sunt de proveniență târzie. De fapt, acestea erau consemnate distinct de Slujba înmormântării, fiind citite de arhiereu sau, în absența lui, de către preotul duhovnic.

20 Această a treia rugăciune a stat la baza primei rugăciuni din slujba actuală a înmormântării preoților și diaconilor, fiindcă, ideile textuale sunt comune. 
duhurilor și a tot trupul...); 6. „Rugăciune de îngropare pentru un episcop” (Doamne Iisuse Hristoase, Mielul lui Dumnezeu...); 7. „Rugăciune la monahul care a adormit” (Stăpâne, Doamne, Dumnezeul noastru, Cel ce singur ai nemurire...) $)^{21}$. Existența rugăciunilor de dezlegare și de iertare, precum și ectenia pentru cei adormiți de la sfârșitul acestui manuscris ne întărește convingerea că ritualul înmormântării, în această perioadă, era integrat în Rânduiala Sfintei Liturghii ${ }^{22}$. Mai observăm faptul că

21 Textul acestei rugăciuni scoate în evidență grija Bisericii față de cei rămași în viață și cărora le acordă atenție și mângâiere pentru pierderea celui drag. Precizăm faptul că această rugăciune apare în Molitfelnicul românesc în Slujba înmormântării preoților și a diaconilor, fiind așezată după a treia pericopă evanghelică. De asemenea, ea face parte și din rânduiala de pomenire a pruncilor morți nebotezați. A se vedea cartea intitulată: Parastase, București, Edit. Institutului Biblic și de Misiune Ortodoxă, 2020, pp. 120-121.

22 Texul ecteniei este următorul: In pace Domnului să ne rugăm; Pentru frații noștri răposați în credință, pentru adormirea, uşurarea şi fericita lor pomenire, Domnului să ne rugăm; Pentru ca să li se ierte lor și nouă toată greșeala cu voie și fără voie, Domnului să ne rugăm; Ca iubitorul de oameni Dumnezeul nostru Cel ce a primit duhul lui să-l rânduiască în loc luminat, în loc de răcorire și dănțuire cu îngeri, unde cei drepți se odihnesc, Domnului să ne rugăm; Milele lui Dumnezeu și iubirea de oameni cerând, pe noi înșine şi unii pe alții și toată viața noastră lui Hristos Dumnezeu să o dăm. Cf. Ioan I. ICĂ jr, op. cit., p. 1032. În Liturghierele românești mai recente s-au introdus atât ectenia pentru cei adormiți, cât şi rugăciunea de dezlegare, Dumnezeul duhurilor..., ca reminiscență a vremurilor în care, în Biserică, Slujba înmormântării era integrată în rânduiala Sfintei Liturghii. A se vedea, Liturghier, București, Edit. Institutului Biblic şi de Misiune Ortodoxă, 2012, pp. 153 și 127. În Liturghierul slavon al lui Macarie, acestea două nu sunt consemnate (a se vedea Liturghierul lui Macarie, trad. Alexandru Stan, Arhiepiscopia Târgoviștei-Biblioteca Academiei Române, 2008), nici în Liturghierul Sfântului Mitropolit Dosoftei, de la Iaşi, din anul 1681. Am consultat și alte ediții, iar în unele dintre acestea, sunt consemnate și Ectenia pentru cei adormiți împreună cu rugăciunea de iertare, precum: Iaşi, 1715 (la Liturghia Sf. Ioan Gură de Aur, indicațiile tipiconale sunt în limba română, în cerneală de culoare roșie, iar rugăciunile și ecfonisele, în slavonă și 1828), Buzău, 1702 (indicații tipiconale în limba române, ecteniile, rugăciunile și ecfonisele, în limba slavonă), Sibiu, 1814 (text românesc integral), Chișinău, 1815, 1859; București, 1895 și 1921. În alte ediții românești acestea nu sunt consemnate, precum: Râmnic, 1833; București, 1741, 1780, 1828; Blaj, 
două dintre rugăciuni sunt pentru episcop și monah, fapt care în timp au constituit premisele alcătuirii unor rânduieli de înmormântare cu elemente distincte specifice fiecărei trepte bisericești și diferitelor categorii de mireni.

\section{Rânduiala înmormântării în lumina Evhologhiilor grecești și românești ${ }^{23}$}

Referindu-se la Slujba înmormântării, ca rânduială ce cuprinde o varietate și o diversitate de texte, I. Fountoulis ${ }^{24}$ menționa următoarele: „De la o singură rugăciune, care constituia inițial aproape întreaga slujbă, treptat, prin contribuția imnografiei bisericești, a evoluat într-o slujbă foarte bogată, care este construită după modelul Utreniei mănăstirești, amestecată chiar cu slujba la care preotul $s$-a săvârșit, cu elemente din Utrenia bizantină parohială sau asmatică" ${ }^{25}$. Într-adevăr, dacă luăm în considerare schema Rânduielii de înmormântare, ea poate fi foarte ușor asociată cu Slujba Utreniei. Pornind de la o singură rânduială de înmormântare, cu timpul aceasta s-a diversificat datorită apariției de noi texte de rugăciuni și imnografice. Astfel, în al doilea mileniu au

1708. În schimb, în edițiile slavone, precum cea de la Kiev, din anul 1862, acestea sunt consemnate. În toate edițiile grecești cercetate, nu sunt consemnate nici ectenia, nici rugcăiunea de dezlegare. În ediția din anul 1995, la sfârșit, s-a introdus Trisaghionul pentru morți. Cel mai probabil, inserția ecteniei pentru adormiți și a rugăciunii, în unele ediții românești de secol XVIII pare să fie de proveniență slavă.

${ }^{23} \mathrm{O}$ lucrare de doctorat de referință cu privire la rânduiala de înmormântare poartă semnătura protopresbiterului grec Themistoclis Christodoulou, intitulată: $H$

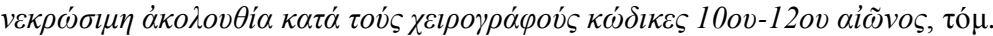

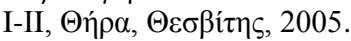

24 Ioannis Fountoulis (1927-2007) a predat Teologia liturgică la Facultățile de Teologie din Atena și Tesalonic. A fost unul dintre cei mai avizați cercetători în domeniul Liturgicii. La Editura Bizantină au fost traduse și publicate, între anii 2008-2011, cele cinci volume ale sale intitulate, Dialoguri liturgice și care conțin sute de răspunsuri la întrebări pe teme liturgice.

25 Ioannis Fountoulis, Dialoguri liturgice, vol. II, trad. Sabin Preda, București Edit. Bizantină, 2009, p. 159. 
apărut slujbe de înmormântare pentru categorii diferite de clerici și mireni. În Molitfelnicele actuale, grecești și românești, putem identifica cinci astfel de slujbe, și anume: la înmormântarea mirenilor, a pruncilor, a preoților și diaconilor, a călugărilor (rânduială care se respectă și în cazul înmormântării arhiereilor) și în Săptămâna Luminată. Desigur, acestea prezintă atât elemente textuale comune, cât și diferente, de la caz la caz. În cadrul cercetărilor întreprinse pe manuscrisele liturgice din secolele X-XII, Th. Christodoulou prezintă și cod. Grott. $Г . \beta$. X din sec. al X-lea. Din prezentarea schițată a rânduielii înmormântării, el ajunge la concluzia că această rânduială este rezultatul contopirii elementelor tipicului monahal savait (de ex. Canonul) cu cele specific tipicului studit, axat preponderent pe cântare (de ex. Antifoane, Condac $)^{26}$. Slujba aceasta apare ca o sinteză a tuturor rânduielilor de înmormântare pe care le cunoaștem astăzi. În fapt, arată Christodoulou, din cuprinsul manuscriselor liturgice din secolele XXII, se desprinde existența unei singure rânduieli de înmormântare cu elemente variabile, cum ar fi canoanele ${ }^{27}$. Un alt aspect important de luat în considerare îl constituie formula de binecuvântare de la început: Binecuvântată este impărăția (...)"28,

${ }^{26}$ Themistoclis Christodoulou, Slujba Înmormântării în tradiția manuscrisă a Evhologhiului bizantin, al nouălea Simpozion Liturgic din Grecia, Volos, 5-7 noiembrie 2007, p. 6, disponibil pe http://www.teologie.net/data/pdf/Christo doulou-slujba-inmormantarii.pdf (data accesării: 24.01.2021).

${ }^{27}$ Ibidem, p. 9.

28 Această formulă era caracteristică tradiției studite transmise și comunităților

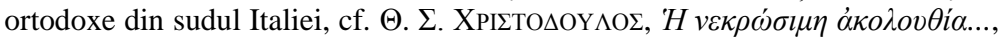

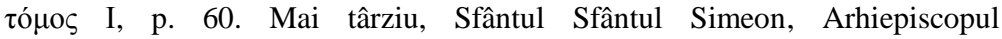
Tesalonicului, descriind rânduielile Vecerniei și Utreniei cântărilor (asmatice) arată că acestea debutau cu aceeași Binecuvântare mare: Binecuvântată este Împărăția Tatălui și a Fiului şi a Sfântului Duh..." (specifică ritului catedral constantinopolitan), care cu timpul s-a păstrat doar în formularul Liturghiei și al unor Sfinte Taine. Cf. Sf. Simeon ArhiePiscopul Tesalonicului, Tratat asupra dogmelor credinței noastre ortodoxe, după principii puse de Domnul nostru Iisus Hristos şi urmaşii Săi, col. „Frumusețile viețuirii creștine”, 2, Suceava, Edit. Arhiepiscopiei Sucevei și Rădăuților, 2003, p. 90 și 96. A se vedea și Nicolae PREDA, „Formula de binecuvântare «Binecuvântat este Dumnezeul nostru...» sau «Binecuvântată este împărăţia...», în Rânduielile de 
specifică îndeosebi Sfintei Liturghii și ritului ecleziastic. Separarea celor două rânduieli s-a fi putut datora faptului că unirea dintre Slujba înmormântării și Sfânta Liturghie necesita pregătirea prealabilă a preotului (ajunarea) în vederea cuminecării cu Sfânta Euharistie, lucru ce nu era totdeauna posibil, dacă ținem seama de faptul că în acea vreme înmormântarea putea avea loc la scurt timp după repausare. Deși aspectul ajunării sfințiților slujitori poate argumenta decizia Bisericii de separare a celor două rânduieli liturgice, totuşi, nu se poate afirma cu exactitate momentul acestei separări. Oricum, începând din secolul al XII-lea, încep să se contureze tiparele liturgice specifice fiecărei categorii de adormiți ${ }^{29}$. românești

4.1. Rânduiala Slujbei de înmormântare în Molitfelnicele

În secolul al XV-lea, în vremea Sfântului Simeon Arhiepiscopul Tesalonicului, slujbele ortodoxe ajunseseră în stadiul final al evoluției lor, îmbrăcând, în mare parte, conținutul și formele pe care le cunoaștem astăzi. Primele traduceri românești ale Molitfelnicelor au fost realizate însă, în bună parte, după edițiile slavone. $\mathrm{O}$ ediție românească importantă pentru studiul nostru este cea apărută la Bălgrad, în anul 1689. Din Rânduiala înmormântării lipsește Canonul alcătuit de Teofan Graptul ${ }^{30}$, deși în edițiile grecești apărute la Veneția, în anii 1602, 1684 și 1691, acesta apare consemnat, lucru ce pare destul de firesc pentru o rânduială altoită pe schema Utreniei, din cadrul căreia nu pot lipsi canoanele. Totodată, un amănunt însemnat este acela că în vechile scrieri se observă lipsa rugăciunilor de iertare introduse în Molitfelnice, începând cu secolul al XVII-lea, separat de Slujba înmormântării și pe care le poate citi, potrivit indicației tipiconale arhiereul, sau în absența acestuia, preotul

la înmormântare (scurtă analiză teologico-liturgică)", în Studia Doctoralia Andreiana, 2/2017, pp. 128-146.

${ }^{29}$ Christodoulou își întemeiază această afirmație pe unele codice care datează din această perioadă (Th. CHRISTODOUlOU, Slujba Inmormântării..., p. 10, n. 43).

30 În schimb, Canonul morților apare menționat în Slujba parastasului, începând cu

p. 723. Despre Teofan Graptul, vezi informații succinte în: Remus Rus, Dicționar enciclopedic de literatură creștină din primul mileniu, București, Edit. Lidia, 2013, p. 826. 
duhovnic. Cea mai veche și singura rugăciune din Slujba înmormântării rămâne, „Dumnezeul duhurilor...”. Pentru a urmări deosebirile dintre textul acesteia consemnat în Molitfelnicul de la 1689 și cel de astăzi, redăm în continuare vechea redactare:

„Dumnedzăul sufletelor și a toate trupurile, moartea ai călcat și pre diiavolul 1-ai deșertat și viiață lumii ai dăruit; Însuți odihneaște, Doamne, sufletul robului Tău (...), în loc luminat, în loc verdos, în loc de răpaos, de unde fuge toată durerea, grija și suspinarea. Și tot păcatul făcut de el, cu cuvântul sau cu lucrul sau cu gândul, ca un Dumnădzău (sic!) milostiv și de oameni iubitoriu, iartă-i. Că nu iaste om care să fie viu, Ție să nu greșască, că Tu sângur ești fără de tot păcatul, direptatea Ta direaptă-i în veaci și cuvântul Tău adevăr. Văzglașen(ie): Că Tu ești înviiarea și viața și odihneala adormitului robului Tău, Hristoase Dumnedzăul nostru, și Ție slavă trimitem, cu fără-de-începutului Tău Părinte și Preasfântului și Bunului și de-viiață-Făcătoriului Tău Duh, acum și pururea și în veacii veacilor"31.

De asemenea, un amănunt ce trebuie menționat este molitva pe care preotul duhovnic o citește la grobnițe, dezlegând pe mort, al cărei text are următorul conținut:

În numele Tatălui și al Fiului și al Duhului Sfânt, pentru rugăciunile preacuratei, biruitoarei noastre de Dumnedzău Născătoarei și pururea Fecioară Maria și a sfintelor puteri cerești, a cinstitului și slăvitului prooroc Înainte-Alergătoriu şi Botedzătoriului Ioan, sfinților şi prealăudaţilor Apostoli și a Sfinților Părinți 318 cei din Necheia. Că, poruncind Domnul Apostolilor Săi dzice: De vor greși înaintea voastră oamenii până în șeapte ori câte șaptedzăci, să iertați pre ei ca să fie iertați și în ceriu, și oare pre care veți dezlega pre pământ, fi-va dezlegat și în ceriu. Ce, după învățătura Domnului Dumnedzău și a Mântuitoriului nostru Isus

31 Ana Dumitran, Alin-Mihai Gherman, Dumitru A. Vanca (eds.), Molităvnic, Bălgrad, 1689, Alba Iulia, Edit. Reîntregirea, 2009, pp. 573 și 575. 
Hristos, iertu-te şi eu, popa (...), fiiul mieu sufletesc (...), ca să fii iertat într-acest veac și în care va să fie, când va veni direptul giudeț să giudece viilor și morților. Că Aceluia să cuvine toată slava, cinstea și închinăciunea, acum și pururea şi în veacii veacilor. $\mathrm{Amin}^{32}$.

După această rugăciune urmează, în continuare, stihirile podobnice. Forma concentrată a acestei rugăciuni de dezlegare a fost introdusă în edițiile moderne, mult mai târziu, începând cu cea din 1950, aceasta fiind a treia rugăciune pe care o citește, potrivit indicației tipiconale, preotul duhovnic ${ }^{33}$. Ea este consemnată și în Micul Evhologhiu grecesc, în rânduiala pe care o citește preotul la ieșirea sufletului, ea figurând ca ultima rugăciune a acestei rânduieli ${ }^{34}$. Un aspect însemnat din Rânduiala înmormântării îl constituie absența sau prezența celor două rugăciuni de iertare de la sfârșit. În vechile ediții românești, precum și în cele grecești, aceste rugăciuni, Doamne, Dumnezeul nostru, Ce ce cu înțelepciunea Ta cea de negrăit... și Stăpâne mult-îndurate, Doamne Iisuse Hristoase, Dumnezeul nostru..., nu apar în Rânduiala înmormântării, ci separat de aceasta. $\mathrm{Nu}$ știm cu exactitate cine este autorul acestora, însă, conform dispoziției, ele se rostesc de către arhiereu pentru iertarea și dezlegarea „grelii afurisanii”. Potrivit rânduielilor bisericești grecești, doar arhiereul poate dezlega afurisania $^{35}$. Însă, prin pogorământ acestea pot fi citite și de preotul duhovnic, dacă apare una dintre următoarele trei situații, şi anume:

32 Ibidem, pp. 655 şi 657.

33 În Molitfelnicele vechi, precum și în cele editate în prima jumătate a secolului al XX-lea, această scurtă rugăciune nu este consemnată. Prima dată apare în Molitfelnicul din 1950, p. 210.

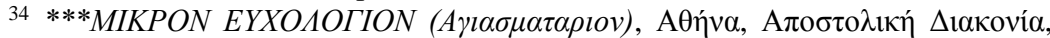

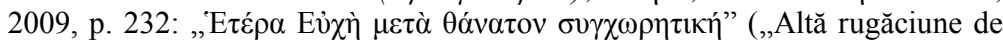
iertare după moarte").

35 I. Fountoulis menționează că aceste două rugăciuni, conform rânduielii din unele manuscrise și în Molitfelnicele tipărite, erau citite pentru odihna celui adormit în timpul Sfintei Liturghii de toți preoții, care urmau să liturghisească, în timpul Proscomidiei, iar de către arhiereu, în timpul Intrării Mari (cf. Ioannis Fountoulis, Dialoguri liturgice, vol. I, trad. Victor Manolache, București, Edit. Bizantină, 2008, p. 112). 
să existe nevoia, să nu fie de față arhiereul, iar preotul să aibă hirotesie în duhovnic. În mod obișnuit, ele se citesc la Liturghiile de sâmbătă și la Slujba parastasului ${ }^{36}$. Aceste rugăciuni apar și în Evhologhiul Mare din 1778, cu indicaţia: EYXAI इYГX

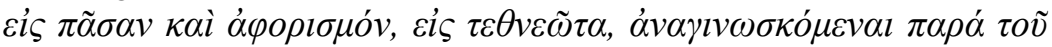

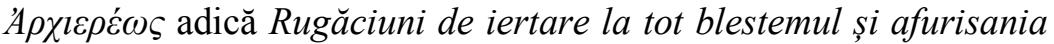
care se citesc la morți de către Arhiereu. La români, aceste două rugăciuni sunt consemnate în Molitfelnice începând cu secolul al XVII-lea, în edițiile de la Iași (ed. Sf. Dosoftei-1681; 1834, 1848) ${ }^{37}$, Râmnic (1706, 1793), București (1722, 1793 1794, 1832), Blaj (1784), Brașov (1811), Buzău (1699, 1701, 1835), Sibiu (1833, 1849), separat de Slujba înmormântării, și poartă următoarea dispoziţie: „Rugăciuni de ertăciune la tot blestemul și afurisania la mort. Care să cetesc de Arhiereu, iar la nevoe să cetesc și de Părintele cel Duhovnicesc de nu va fi Arhiereu". O însemnare interesantă și suplimentară, similară cu cea menționată de I. Fountoulis (la nota 35) cu referire la momentele rostirii acestor două rugăciuni de iertare, apare în Molitfelnicele editate la Iași, în anul 1681 și Buzău, în anul 1699, în care se pot citi urmăroarele: Iară să cade a ști, că Molitvele acestea să citesc așa. La Proscomidie citesc acestea cu umilință toți Preoții cei ce voesc să facă Liturghie. Iară la Vohodul cel mare eșind preoții afară den oltariu cu sfintele Daruri și stând ei, Arhiereul zice acestea cu glas mare, cu umilință și cu lacrămi. Iară când se sfârșesc acestea, sculânduse ia sfintele ${ }^{38}$. Apoi, în ediția din anul 1864, apărută la București, în vremea arhipăstoririi Mitropolitului Nifon, aceste rugăciuni sunt consemnate, între pp. 155-157, imediat după textul

${ }^{36}$ I. FounToulis, op. cit., vol. I, p. 113.

37 În vechile ediții, după rugăciunea Dumnezeul duhurilor..., rostită la sfârșitul Slujbei înmormântării, este consemnată următoarea formulă pe care o rostește preotul: Veșnică pomenire ție, vrednice de fericire și pururea pomenite frate al nostru, care traduce formula corespondentă din Evhologhiul grecesc: Ai $\omega v i$ í

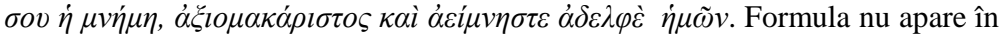
Molitfelnicul din 1950, iar în ediția din 2013, această formulă este consemnată la Slujba Parastasului.

${ }^{38}$ Indicația din acest Molitfelnic reia dispoziția prevăzută în vechile Evhologhii grecești, după cum reiese din cele menționate și de I. Fountoulis. 
evanghelic de la Ioan, iar din ediția sinodală din anul 1888, ele sunt introduse separat, între pp. 512-515. În ediţia tipărită la Blaj, în timpul arhipăstoririi arhiepiscopului Alexandru Nicolescu, apar aceste rugăciuni, de asemenea, separat de Slujba înmormântării ${ }^{39}$. În sfârşit, în ediţiile sinodale din anii 1920 și 1937, rugăciunile sunt transferate în cadrul Slujbei de înmormântare, în locul unde se găsesc şi acum. Începând cu edițiile apărute în vremea Patriarhului Justinian Marina şi până în zilele noastre, după citirea pericopei evanghelice sunt consemnate cele trei rugăciuni, în ordinea în care apar și astăzi.

\section{Aspecte pastorale}

Slujba de înmormântare abundă în învăţături teologice și duhovnicești. Formularul liturgic al acestei slujbe, alcătuit din cântări, texte biblice și rugăciuni, constituie o cateheză duhovnicească unică ce poate avea un impact benefic asupra familiei întristate şi asupra participanţilor la acest ceremonial de înmormântare, deoarece mesajul ei face referire la crearea omului, la căderea sa din starea harică primordială, la restaurarea omului în Iisus Hristos Fiul lui Dumnezeu, Noul Adam, și la faptul că viața nu se sfârșește odată cu moartea naturală, aceasta fiind poarta de intrare în stadiul plenar al eternităţii. Tot din textul slujbei aflăm că vor urma judecata particulară și cea de obşte. Hotărâtoare pentru starea omului sunt credința și faptele sale bune, lucrate prin Harul lui Dumnezeu. Acest „memorial”, cum arătam la începutul acestui studiu, este un bun prilej de fixare a elementelor de antropologie creștină ortodoxă, legate de constituţia dihotomică a omului și de valoarea lui ca persoană creată după chipul lui Dumnezeu și în perspectiva veșnicei asemănări cu El, dar și de conștientizare a sensului ceresc și transcendent al existenței umane, a faptului că toate lucrurile din lume sunt efemere, alterabile și inconsistente, iar alipirea de acestea trup şi suflet poate constitui o primejdie în calea

39 Titlul identic cu cel din ediția Sfântului Mitropolit Andrei Șaguna ne încurajează să afirmăm că Greco-catolicii le-au preluat din această ediție sibiană. 
mântuirii şi desăvârşirii omului (cf. Evloghitariilor și Stihirilor idiomele). Prin urmare, trupul împreună cu sufletul omului, participă aici, pe pământ, dar și în veșnicie la viața de comuniune cu Dumnezeu, aceasta fiind menirea sa. Totodată, slujba insuflă celor prezenți speranța în înviere și în iubirea lui Dumnezeu pentru noi, Care ne va aduce prin moarte și înviere în Împărăția Sa. Astfel, mesajul pe care-l transmite tuturor este adevărul că în Hristos moartea nu mai are ultimul cuvânt, aceasta fiind abolită de Mântuitorul Iisus Hristos, Care este Învierea și Viața. Punerea în mormânt a lui Hristos și Învierea Sa au pentru creștini o valoare arhetipală, iar moartea și învierea noastră se petrec după exemplul Mântuitorului nostru. Totodată, din textul slujbei, primim şi îndemnul de a ne trăi viaţa în conformitate cu poruncile lui Dumnezeu și de a cultiva cât mai intens legătura cu El. Faptul că această slujbă este în mare parte cântată, ne arată că în ea trebuie săși găsească cei încercați alinarea şi mângâierea durerii, dar și speranța în înviere și în reîntâlnirea cu cei adormiți, în lumina cea neapropiată și veşnică a Preasfintei Treimi. Nu putem să nu exprimăm aici ideea că Biserica respinge practica necreștină a incinerării, arătând că trupul nu este creat dintr-o materie rea, după cum susțineau religiile antichității, ci că el este creat de Dumnezeu din pământ, dar dăruit cu privilegiul de a participa la viața duhovnicească și la lucrarea mântuitoare, împreună cu sufletul său. Din perspectivă creștină, prin înviere, trupul se transfigurează sau se îndumnezeiește, umplându-se de sfintenia harului dumnezeiesc ${ }^{40}$.

${ }^{40}$ Pentru o temeinică documentare privitoare la valoarea trupului în Ortodoxie și la semnificația și valoarea eternă a omului în integralitatea sa, pot fi cercetate următoarele cărți semnate de teologul ortodox francez Jean Claude LARCHET, Tradiția ortodoxă despre viața de după moarte, Edit. Sophia, 2006; Semnificația trupului în Ortodoxie, București, Edit. Basilica, 2010; Sfârșit creștinesc vieții noastre, fără durere, neînfruntat, în pace..., București, Edit. Basilica, 2012 (îndeosebi, capitolul al VII-lea, în care se vorbește despre incinerare și despre argumentele Bisericii Ortodoxe împotriva acestei practici necreștine). În literatura teologică românească, menționăm lucrarea relativ recentă a lui Răzvan BRUDIU, Incinerarea. Provocare misionară sau contramărturie creștină, Cluj-Napoca, Presa Universitară Clujeană, 2018. Împotriva acestei practici, Sfântul Sinod al Bisericii Ortodoxe Române a emis hotărârea 
În zilele noastre, când lumea suferă din pricina pandemiei de Coronavirus, când incertitudinea și groaza au pus stăpânire pe sufletele oamenilor, cu atât mai mult preotul este chemat să fie alături de păstoriții săi, încurajându-i și mângâindu-le sufletele întristate pentru pierderea celor dragi. Săvârșirea slujbei de înmormântare, cu mult tact pedagogic și pastoral, arată grija Bisericii, în calitatea ei de mamă spirituală, față de fiii ei duhovnicești trecuți la cele veșnice, dar și iubirea și compasiunea acesteia față de cei aflați în viață și care au nevoie de alinare, vindecare și luminare pe calea mântuirii.

\section{Slujba înmormântării în tradiția muzicală bisericească românească}

În repertoriul românesc de strană se păstrează câteva contribuții ale unor mari profesori, psalți și compozitori români, creații muzicale care împodobesc Slujba de înmormântare. Lucrul acesta se face simțit îndeosebi începând cu secolul al XIX-lea, secolul reformării cântului bisericesc. Dintre dascălii de muzică psaltică din țara noastră amintim, în primul rând, pe Anton Pann, care - într-una din publicațiile sale- introduce Rânduiala inmormântării mirenilor (care s-a uitat să se puie la IrmologhiulCatavasier), ce cuprinde: „Ectenia pentru cei adormiț”, pe glasul al 5-lea, „Aliluia” cu cele două tropare, pe glasul al 8-lea, stihuri din cele trei stări ale catismei a XVII-lea, „Binecuvântările morților”, pe glasul al 5-lea, irmoasele al III-lea, al VI-lea și al IX-lea din Canonul lui Teofan Graptul, pe glasul al 6-lea, condacul „Cu sfinții odihnește...”, pe glasul al 8-lea, „Veșnică pomenire” pe glasul al 3lea ș.a ${ }^{41}$, stihira „Plâng și mă tânguiesc...”, pe glasul al 8-lea, compusă la cererea lui Teofilact, cântărețul mănăstirii Cernica ${ }^{42}$, alte două variante, dintre care, una dedicată arhimandritului

nr. 4529/5 iulie 2012, care menține în vigoare hotârârea din 15 iunie 1928, reconfirmată în 20 februarie 1933. Vezi cartea cultică intitulată Parastase, București, Edit. Institutului Biblic și de Misiune Ortodoxă, 2020, pp. 122-124. ${ }^{41}$ Vezi Rânduiala Sfintei și Dumnezeieștei Liturghii, București, 1847, între pp. 79-88.

${ }^{42}$ Vezi Privighierul, 1848, pp. 433-434. 
Nicandru, starețul mănăstirii Cernica ${ }^{43}$, celelalte stihirile idiomele ${ }^{44}$ și cântarea calofonică, „Pământule primește...”45.

De asemenea, Ștefanache Popescu ne-a lăsat cântări pentru Rânduiala înmormântării mirenilor, publicate de arhiereul Nifon Ploieșteanu ${ }^{46}$. Acestea au fost editate ulterior de Ion PopescuPasărea, discipolul și urnaşul său la catedră. Ion Popescu-Pasărea a preluat și completat ulterior creația înaintașului său, publicând-o în următoarele culegeri: Colecțiune de cântările Sfintei Liturghii, scrise pe muzica bisericească (1905, 1925), Cântări la Tedeum, Sfeștanie, Cununie, Inmormântare și Parastas (1910) și Culegere de cântări bisericești ce se cântă de către preoți în sobor la diverse servicii bisericești (1940). Un alt compozitor, mai puțin cunoscut, a fost Gheorghe Cazana. Acesta a tradus din limba greacă în limba română cântările din Slujba înmormântării după Tipicul patriarhal de la Constantinopol ${ }^{47}$. In Moldova, Dimitrie Suceveanu, paharnicul și protopsaltul mitropoliei, a acordat, la rândul său, atenție rânduielii înmormântării mirenilor, tipărind în anul 1848, la sfârșitul Irmologhionului său Începutul rânduielii ingropării mirenilor tradus din grecește în românește din porunca Inaltpreasfințitului Proin Mitropolit Veniamin. De la protosinghelul Varlaam Barancescu ne-au rămas cele opt stihiri idiomele, puțin cunoscute până în prezent ${ }^{48}$. În anul 1947, arhidiaconul profesor Anton Uncu publica, la rândul său, Slujba înmormântării care cuprinde: Aliluia, troparele, stihuri din cele trei stări ale catismei a XVII-a, pe glasul al 2-lea, Binecuvântările morților, în maniera tradițională a celor care se cântă și astăzi la

${ }^{43}$ Vezi Noul Doksastar, tom. II, 1853, pp. 124-126.

${ }^{44}$ Ibidem, pp. 114-121.

45 Ms.rom. 2544 din Biblioteca Mănăstirii Tismana, pp. 103-105, cu indicația: „se cântă la îngroparea mortului”.

${ }^{46}$ Nifon N. PloeȘTEANU, Carte de musică bisericească, București, Edit. Joseph Göbl („Guthenberg”), a Cărților Bisericești și Carol Göbl 20, 1902, pp. 192-207.

47 Aceste cântări se găsesc în ms. rom. I -56 din Biblioteca Sfântului Sinod. A se vedea „Notă asupra ediției” din ***Antologie de cântări psaltice, tomul al IIlea, Cântări la Slujba Inmormântării, București, Asociația „Nectarie Protopsaltul", 2007.

${ }^{48}$ Vezi, ms. rom. II-67 din Biblioteca Sfântului Sinod. 
strană $^{49}$, sedelnele Odihnește, Mântuitorule... Cela ce ai răsărit..., Irmoasele cântărilor 3, 6 și 9, Condacul, Idiomelele, stihira Plâng și mă tânguiesc, pe glasul al 8-lea, după melodia „Vai! Înnegrite suflete" de Macarie Ieromonahul, Văzându-mă zăcând..., pe glasul al 6-lea de Dimitrie Suceveanu și Veșnică pomenire. În a doua jumătate a secolului al XX-lea, în timpul arhipăstoririi Patriarhului Justinian Marina s-au publicat, pe dublă notație, psaltică și liniară, Cântări la Taine şi Ierurgii, în revista Studii Teologice, nr. 12/1964. Acestea toate, aparținând profesorilor Anton Pann, Ștefanache Popescu și Ion Popescu Pasărea, au fost republicate de Pr. prof. Nicu Moldoveanu în două ediţii ${ }^{50}$. Merită menţionat că aceste cântări tradiționale de la înmormântărea mirenilor au fost publicate, în timpul arhipăstoririi Patriarhului Teoctist, la sfârșitul Panihidei, prin grija Arhid. prof. Sebastian Barbu-Bucur ${ }^{51}$. O ediție completă a cântărilor din Slujba înmormântării, în general, a fost publicată de Asociația „Nectarie Protopsaltul”, în anul 2007, cu binecuvântarea Patriarhului Teoctist și cu sprijinul material al mănăstirii athonite Vatoped. Ediția, apărută în notație neumatică, este îngrijită de Gabriel Duca şi Valentin Gheorghe. Tipărită în condiții grafice de excepție, în format mai mic, culegerea cuprinde întreaga creație românească consacrată Slujbei înmormântării mirenilor, pruncilor și călugărilor, Rânduiala ridicării Panaghiei și cântări calofonice sau frumos glăsuitoare. Printre autorii cântărilor pot fi menționați Macarie Ieromonahul, Anton Pann, Dimitrie Suceveanu, Ștefanache Popescu, Ion Popescu-Pasărea, Gheorghe

49 Vezi Anton UnCU, Antologhion, București, Tipografia Cărților Bisericești, 1947, pp. 186-207.

${ }^{50}$ Nicu Moldoveanu (ed.), Cântări la Sfintele Taine și la Ierurgii și alte cântări religioase, București, Edit. Institutului Biblic și de Misiune Ortodoxă al Bisericii Ortodoxe Române, 2002, pp. 39-76 și Cântări la Sfintele Taine și la Ierurgii, București, Edit. Institutului Biblic și de Misiune Ortodoxă, pp. 81128. Luminândele de la Slujba înmormântării preoților și pruncilor sunt notate de Pr. Prof. Nicu Moldoveanu.

${ }^{51}$ Vezi, Panihida, ediția a III-a, București, Edit. Institutului Biblic și de Misiune al Bisericii Ortodoxe Române, 1992, anexă, pp. I-XXXII, selecționare și transcriere în notația liniară: Sebastian Barbu-Bucur (cuprinde și câteva cântări de la înmormântarea călugărilor). 
Cazana, Varlaam Protosinghelul, Victor Ojog etc., dar și tineri creatori de cântări, precum Virgil Nanu, Gabriel Duca şi Cornel Coman, care cu dragoste și iscusință au completat acest repertoriu $^{52}$. Și în spațiul transilvănean au existat astfel de preocupări. Toate cântările publicate aici sunt, în exclusivitate, în notație liniară, dar tot în cele opt glasuri, însă cu specific aparte decât cele menționate până acum. Printre editori, amintim pe părintele Dimitrie Cunțanu ${ }^{53}$, pe Arhid. Prof. Ioan Brie ${ }^{54}$ și pe Pr. Prof. Univ. Dr. Vasile Stanciu ${ }^{55}$.

\section{Concluzii}

Asemenea Sfintelor Taine, rânduiala de înmormântare era săvârșită în cadrul comuniunii euharistice, adică în interiorul Sfintei Liturghii. Acest lucru este confirmat de manuscrisele liturgice vechi. Chiar rânduiala actuală, care este rezultatul contopirii elementelor tipicului studit constantinopolitan cu cele proprii tipicului savait de tip monastic, păstrează reminiscențe care stau ca mărturie a acestei legături organice. În decursul timpului, în Rânduiala înmormântării, alcătuită după schema Utreniei, au pătruns elemente ale imnografiei studite (Antifoane, Condac) și ale imnografiei savaite (Canonul), ajungându-se ca în secolele X-XII Slujba înmormântării să cunoască o formă unică. Acesteia, i se adaugă rugăciuni și texte imnografice (precum sunt canoanele) proprii diferitelor categorii de adormiți: mireni, prunci, preoți și diaconi și călugări și arhierei. În epoca Sfântului Simeon al Tesalonicului Slujba înmormântării mirenilor ajunsese la forma pe care o cunoaștem astăzi. Plină de semnificații și învățături teologice și duhovnicești, această rânduială liturgică îmbracă atât un caracter catehetic-educativ, cât și unul pastoral, fiind $o$ autentică lecție despre importanța și rolul trăirii vieții pământești

52 Titlul volumului apare la nota 43.

53 Dimitrie CunțAnu, Cântări funebrale pentru cor de bărbați, Sibiu, 1903.

${ }^{54}$ Ioan BRIE, Cântări la Cununie și înmormântare, Oradea, 1990.

55 Vasile STANCIU, Cântări la înmormântarea mirenilor după melodii tradiționale din Transilvania, pe o singură voce, Cluj-Napoca, Edit. Renașterea, 2019. 
în duh evanghelic, ca pregătire pentru marea trecere spre cea mai înaltă treaptă a sfințeniei și a comuniunii veșnice cu Preasfânta Treime. Săvârșirea acestei rânduieli cu deplină responsabilitate și cu mult tact de către preoți și descoperirea credincioșilor Bisericii noastre a sensurilor ei existențiale adânci, pot conferi acestora un imbold pentru viața duhovnicească. $O$ caracteristică a acestei frumoase slujbe este aceea că ea se cântă aproape în întregime. Poate că nicio altă slujbă ortodoxă nu are acest privilegiu. Astfel, datorită melodicității și caracterului luminos și angajant al cântărilor, această rânduială are menirea de a transmite celor îndurerați speranță, întărire sufletească, tărie în practicarea credinței și mângâiere. Unii dintre cei mai renumiți protopsalți și profesori de muzică bisericească români au alcătuit cântările din Slujba înmormântării mirenilor, tocmai pentru a împodobi această rânduială liturgică și pentru a susține lucrarea misionară a Bisericii noastre în mijlocul fiilor ei duhovnicești. În contextul pandemiei în care ne găsim, abordarea temei înmormântării este actuală, fiindcă ne poate redescoperi sensul real și profund al vieții, de care, din nefericire, lumea contemporană se îndepărtează din ce în ce mai mult.

$\cos 80$

\section{Bibliografie selectivă}

1. ***Antologie de cântări psaltice, tomul al II-lea, Cântări la Slujba Înmormântării, București, Asociația „Nectarie Protopsaltul”, 2007.

2. BRANIȘTE, Ene, Liturgica Specială pentru institutele teologice, București, Edit. Institutului Biblic și de Misiune al Bisericii Ortodoxe Române, 1980.

3. BRIE, Ioan, Cântări la Cununie şi înmormântare, Oradea, 1990.

4. CunȚANu, Dimitrie, Cântări funebrale pentru cor de bărbați, Sibiu, Tiparul lui W. Krafft, 1903.

5. Dumitran, Ana, Gherman, Alin-Mihai, Vanca, Dumitru A (eds.), Molităvnic, Bălgrad, 1689, Alba Iulia, Edit. Reîntregirea, 2009.

6. Eusebiu de CeZAREeA, Viața lui Constantin cel Mare. Scrieri, partea a doua, introd. Emilian Popescu, trad. Radu Alexandrescu, col. „Părinți și Scriitori Bisericești”, 14, București, Edit. Institutului Biblic și de Misiune al Bisericii Ortodoxe Române, 1991. 
7. Fer. Augustin, Confessiones (Mărturisiri), trad. Nicolae Barbu, introd. Ioan Rămureanu, București, Edit. Institutului Biblic și de Misiune al Bisericii Ortodoxe Române, 1994.

8. Fountoulis, Ioannis, Dialoguri liturgice, vol. I/II, trad. Victor Manolache/Sabin Preda, Editura Bizantină, București, 2008/2009.

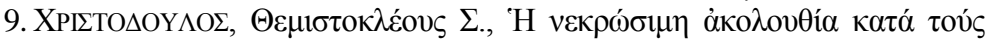

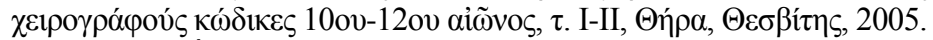

10. IDEM, Slujba Inmormântării în tradiția manuscrisă a Evhologhiului bizantin, al nouălea Simpozion Liturgic din Grecia, Volos, 5-7 noiembrie 2007, disponibil pe: http://www.teologie.net/data/pdf/ Christodoulou-slujba-inmormantarii.pdf.

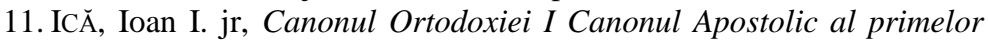
secole, Sibiu, Deisis/Stavropoleos, 2008.

12. LARCHET, Jean Claude, Tradiția ortodoxă despre viața de după moarte, Edit. Sophia, 2006.

13. IDEM, Semnificația trupului în Ortodoxie, București, Edit. Basilica, 2010.

14. IDEM, Sfârșit creștinesc vieții noastre, fără durere, neînfruntat, în pace..., București, Edit. Basilica, 2012.

15. ***Liturghierul lui Macarie, trad. Alexandru Stan, Arhiepiscopia Târgoviștei-Biblioteca Academiei Române, 2008.

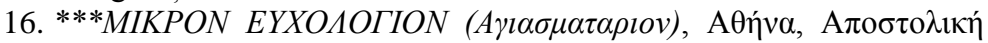
$\Delta$ 1aкоvía, 2009.

17. MiLoșEvici, Nenad S., Dumnezeiasca Liturghie - centrul cultului în Ortodoxie. Legătura indisolubilă a sfintelor Taine cu dumnezeiasca Liturghie, trad. Ioan Ică sr, Sibiu, Deisis, 2012.

18. Moldoveanu, Nicu (ed.), Cântări la Sfintele Taine și la Ierurgii și alte cântări religioase, Nicu Moldoveanu, București, Edit. Institutului Biblic și de Misiune Ortodoxă, 2002.

19. Moldoveanu, Nicu (ed.), Cântări la Sfintele Taine şi la Ierurgii, București, Edit. Institutului Biblic și de Misiune Ortodoxă, 2015.

20. ***Molitfelnic, București, Edit. Institutului Biblic şi de Misiune Ortodoxă, 2009, 2012, 2019.

21. NifON N. PloeșteAnu, Carte de musică bisericească, București, Edit. Joseph Göbl („Guthenberg”), a Cărților Bisericești și Carol Göbl 20, Strada Doamnei, 1902.

22. PANN, Anton, Rânduiala Sfintei și Dumnezeieștei Liturghii, București, 1847.

23. IDEM, Privighierul, București, 1848.

24. IDEM, Noul Doksastar, tom. II, București, 1853.

25. ***Parastase, București, Edit. Institutului Biblic și de Misiune Ortodoxă, 2020. 
26. PREDA， Nicolae, „Formula de binecuvântare «Binecuvântat este Dumnezeul nostru...» sau «Binecuvântată este împărăţia...», în Rânduielile de la înmormântare (scurtă analiză teologico-liturgică)", în Studia Doctoralia Andreiana, 2/2017, pp. 128-146.

27. PSEUDO-DIONISIE AREOPAGITUL, Ierarhia cerească, Ierarhia pământească, trad. Cicerone Iordăchescu, Chișinău, Tipografia Eparhială „Cartea Românească”, 1932.

28. POPESCU, Niculae M., „Diortosind Molitfelnicul”, în Biserica Ortodoxă Română, 11-12/1937, pp. 695-712.

29. Sf. Grigorie TeOlogul, Panegiric (Cuvânt de laudă) la Sfântul Vasile cel Mare, trad. Nicolae Donos, București, Edit. Institutului Biblic și de Misiune Ortodoxă, 2009.

30. SF. IOAN GURĂ-DE-AUR, Predici la sărbători împărătești şi cuvântări de laudă la sfinți, trad. Dumitru Fecioru, București, Edit. Institutului Biblic și de Misiune al Bisericii Ortodoxe Române, 2002.

31. SF. SimeOn ARHIEPISCOPUl TeSAlONICUlui, Tratat asupra dogmelor credinței noastre ortodoxe, după principii puse de Domnul nostru Iisus Hristos și urmaşii Săi, col. „Frumusețile viețuirii creștine”, 2, Suceava, Edit. Arhiepiscopiei Sucevei și Rădăuților, 2003.

32. STANCIU, Vasile, Cântări la înmormântarea mirenilor după melodii tradiționale din Transilvania, pe o singură voce, Cluj Napoca, Edit. Renaștearea, 2019.

33. TAFT, Robert, Ritul bizantin - scurtă istorie -, trad. Dumitru Vanca și Alin Mehes, Alba Iulia, Edit. Reîntregirea, 2008.

34. UNCU, Anton, Antologhion, București, Tipografia Cărţilor Bisericești, 1947. 